\title{
Phosphate Biofertilizer, Row Spacing and Plant Density Effects on Corn (Zea mays L.) Yield and Weed Growth
}

\author{
Gholam Reza Mohammadi*, Mohammad Eghbal Ghobadi, Saeed Sheikheh-Poor \\ Department of Crop Production and Breeding, Faculty of Agriculture and Natural Resources, Razi University, Kermanshah, Iran. \\ Email: "mohammadi114@yahoo.com
}

Received August 15 ${ }^{\text {th }}$, 2011; revised September 20 ${ }^{\text {th }}, 2011$; accepted October $9^{\text {th }}, 2011$

\begin{abstract}
A field study was conducted at the Agricultural Research Farm of Razi University, Kermanshah, Iran to investigate the effects of phosphate biofertilizer, row spacing and plant density on corn yield and weed growth. The experiment was a factorial with three factors arranged in a randomized complete block design with three replications. The first factor was phosphate biofertilizer (inoculation and non-inoculation), the second was row spacing (conventional $(75 \mathrm{~cm})$ and re-

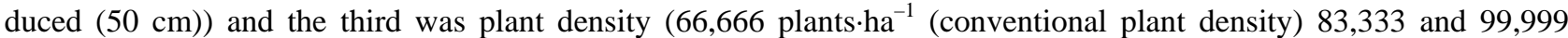
plants $\cdot \mathrm{ha}^{-1}$ (1.25 and 1.5 times the conventional plant density, respectively)). Results indicated that corn yield and weed growth were significantly influenced by row spacing and plant density. So that, corn yield improved and weed biomass diminished in response to increasing plant density and decreasing row spacing. However, phosphate biofertilizer had no significant effect on corn yield, whereas, weed biomass was notably increased when phosphate biofertilizer was applied. Overall, this study revealed that both yield and weed control in corn field can be improved by alteration of the planting arrangement.
\end{abstract}

Keywords: Corn; Phosphate Biofertilizer; Planting Arrangement; Weed

\section{Introduction}

Corn is one of the most important cereals which is widely planted in Iran. Corn is planted in a wide row spacing $(75 \mathrm{~cm})$ and a low plant density (66,666 plants. $\mathrm{ha}^{-1}$ ). These row spacing and plant density can reduce potential crop yield and economic return due to less efficient use of available resources such as light, water and nutrients by the corn plants and increase soil erosion and water evaporation (between the crop rows) and weed infestation. The optimal row width and plant density in corn production systems continue to narrow and intensify as corn genetics evolve [1]. Narrow rows make more efficient use of available resources and should allow quicker canopy closure and thus quicker shading of the ground thereby improving weed control in corn [2]. As plant densities continue to increase, an obvious course of action would be to narrow row spacing, distribute plants more equidistantly across the field and reduce interplant competition [3]. However, the studies on corn row spacing and plant density have produced inconsistent results.

According to Johnson et al. [4] there was no yield advantage of planting corn in narrow rows. Farnham [3] found that corn grown in $76 \mathrm{~cm}$ row spacing produced

\footnotetext{
${ }^{*}$ Corresponding author.
}

higher yields than that grown in $38 \mathrm{~cm}$ rows. However, Porter et al. [5] reported a corn yield advantage (7\%) for narrowing row spacings from $76 \mathrm{~cm}$ to 51 or $38 \mathrm{~cm}$. Cox et al. [6] also suggested that corn grown in narrow row widths had a yield advantage over wider rows. Shapiro and Wortmann [7] also reported that corn grain yield was greater with narrow row spacing. In another study, corn grain yield increased $2 \%$ and $4 \%$ when row width was decreased from $76 \mathrm{~cm}$ to $56 \mathrm{~cm}$ and $38 \mathrm{~cm}$, respectively [8]. In this study, the highest corn yield was obtained at the highest plant density $\left(90,000\right.$ plants $\left.^{-} \mathrm{ha}^{-1}\right)$ as compared with lower plant densities. Generally, increasing plant density usually increases corn grain yield until an optimum number of plants per unit area is reached [2]. However, the optimal plant density level and row width for corn may vary with location [8].

Phosphorus (P) is only second to nitrogen as a mineral nutrient required for plant growth [9]. Most of the soils in Iran are phosphorous deficient or marginally deficient [10]. In many countries such as Iran, a massive increase in the rate of application of chemical fertilizers has been adopted to ameliorate this deficiency. According to Besharati et al. [10] the current annual consumption of phosphate fertilizers in Iran is approximately 750 thousand tons, about 250 thousand of which are produced in 
the country and the rest are imported. A large proportion of the phosphorous content of chemical fertilizers is quickly transformed to the insoluble form such as calcium phosphate, thereby making them unavailable to plants. Moreover, there are global concerns that the unbalanced use of chemical fertilizers has a role in environmental degradation and climate change [11,12].

In an attempt to reduce environmental risk and cost with chemical fertilizer use, phosphorous biofertilizers (phosphate-solubilizing microorganisms) has been considered as possible substitutes for traditional mineral $\mathrm{P}$ fertilizer. These microorganisms have been distinguished by their relative ability to dissolve calcium phosphate and apatite in association with plant roots. This activity was attributed to organic acid and chelating metabolites produced by these microorganisms [13-15]. However, phosphate biofertilizer have shown variation in their performance in related to their environmental condition.

The present study was conducted to investigate the effects of planting arrangement and phosphate biofertilizer on corn yield and weed growth in Kermanshah, west Iran.

\section{Materials and Methods}

The study was carried out in 2010 at the Agricultural Research Farm of Razi University, Kermanshah, west Iran. The soil type was a silty clay with an average $\mathrm{pH}$ of 8.1 and $0.8 \%$ organic matter. The land was plowed and disked before planting. Nitrogen fertilizer was applied as urea according to the soil test recommendation. The corn cultivar used was "KSC 704" (a grain corn cultivar that is commonly planted in the region). The crop was planted on 2 June 2010. Corn is an irrigated crop in Iran, therefore, it is not dependent on the seasonal rainfall. Irrigations were carried out as needed throughout the growing season (at 7 - 9 day intervals).

The experiment was a factorial with three factors arranged in a randomized complete block design with three replications. The first factor was phosphate biofertilizer (inoculation and non-inoculation), the second was row spacing (conventional $(75 \mathrm{~cm})$ and reduced $(50 \mathrm{~cm})$ ) and the third was plant density $\left(66,666\right.$ plants $\cdot \mathrm{ha}^{-1}$ (conventional plant density) 83,333 and 99,999 plants $\cdot \mathrm{ha}^{-1}$ (1.25 and 1.5 times the conventional plant density, respectively)). Before planting, corn seeds were inoculated with phosphate biofertilizer (Barvar 2) containing the phosphate solubilizing microorganisms Bacillus lentus and Pseudomonas putida.

Each plot consisted of six corn rows of $7.5 \mathrm{~m}$ long with predetermined row spacings and plant densities. $5 \mathrm{~m}$ length of each plot was maintained weed free by hand weeding to evaluate corn plant traits. Hand weeding was carried out as needed throughout the growing season.
The remaining area (2.5 $\mathrm{m}$ in length) was maintained un-weeded to assess the effect of phosphate biofertilizer and planting arrangement on weed growth.

At maturity, the corn yield and yield components were measured on the weeded section of each plot. The corn ears located $6 \mathrm{~m}^{2}$ from each plot were harvested by hand, then allowed to dry at $80^{\circ} \mathrm{C}$ to a constant weight and then seed yield was obtained. Before final harvesting corn yield components including the number of ears per plant and the number of seeds per ear were determined on five randomly selected plants in the center rows of each plot. 100 -seed weight was measured according to the recommendation of the International Seed Testing Association (ISTA) [16]. Moreover, weed biomass was also determined by harvesting the weeds at ground level in two random $0.5 \times 0.5 \mathrm{~m}$ quadrats on the un-weeded section of each plot. Then weeds were dried at $80^{\circ} \mathrm{C}$ to the constant weights and weighed. The data analyses were carried out using SAS software [17].

\section{Results and Discussion}

Analysis of variance (Table 1) indicated that corn yield was significantly influenced by row spacing and plant density (at the 0.01 level of probability). Phosphate biofertilizer had no significant effect on corn yield and yield components. Weed biomass was significantly affected by phosphate biofertilizer and plant density. Moreover, there was a significant two-way interaction (row spacing $\times$ plant density) for weed biomass. However, other two and three-way interactions were not statistically significant for the traits under study (Table 1).

In general, corn yield was enhanced when plant density was increased or row spacing was decreased. Corn yield in the reduced row spacing $(50 \mathrm{~cm})$ was $19.71 \%$ higher than that in the conventional row spacing $(75 \mathrm{~cm})$ (Figure 1). Moreover, increased plant density from 66,666 (conventional) to 83,333 and 99,999 plants·ha ${ }^{-1}$ (1.25 and 1.5 times the conventional plant density, respectively) improved corn yield by 22.29 and $40.71 \%$, respectively. Although there was no significant difference between 1.25 and 1.5 times the conventional plant densities for corn yield (Figure 2). Yield improvement with narrow rows and high plant densities can be attributed to greater solar energy interception, shading the soil surface more completely during the early part of the growing season $[18,19]$. However, yield components were not significantly influenced by row spacing or plant density (Table 1). It is similar to the results obtained by Turgut $e t$ al. [2] as reported that row spacings and plant densities did not significantly affect corn yield components such as the number of ear per plant. It can be concluded that improved corn yield at the narrower rows or the higher plant densities was mainly due to increasing the number 
Table 1. Analysis of variance of the traits under study.

\begin{tabular}{cccccc}
\hline \multirow{2}{*}{ Source of Variance } & \multicolumn{5}{c}{ Mean Square } \\
\cline { 2 - 6 } & Yield & Ear/plant & Seed/ear & 100 -seed weight & Weed biomass \\
\hline Replication & $47737.15 \mathrm{~ns}$ & $0.00070 \mathrm{~ns}$ & $2823.41 \mathrm{~ns}$ & $8.1476 \mathrm{~ns}$ & $886869.47^{* *}$ \\
Phosphate biofertilizer (PB) & $83616.49 \mathrm{~ns}$ & $0.00071 \mathrm{~ns}$ & $5565.16 \mathrm{~ns}$ & $0.0005 \mathrm{~ns}$ & $175829.26^{*}$ \\
Row spacing (RS) & $390558.54^{* *}$ & $0.00071 \mathrm{~ns}$ & $1320.11 \mathrm{~ns}$ & $2.3665 \mathrm{~ns}$ & $56346.10 \mathrm{~ns}$ \\
Plant density (PD) & $459200.73^{* *}$ & $0.00093 \mathrm{~ns}$ & $5653.15 \mathrm{~ns}$ & $12.7180 \mathrm{~ns}$ & $290915.12^{* *}$ \\
PB $\times$ RS & $105350.12 \mathrm{~ns}$ & $0.00004 \mathrm{~ns}$ & $19228.44 \mathrm{~ns}$ & $3.5407 \mathrm{~ns}$ & $87017.13 \mathrm{~ns}$ \\
PB $\times$ PD & $43546.06 \mathrm{~ns}$ & $0.00031 \mathrm{~ns}$ & $10780.33 \mathrm{~ns}$ & $3.3667 \mathrm{~ns}$ & $79556.45 \mathrm{~ns}$ \\
RS $\times$ PD & $28326.223 \mathrm{~ns}$ & $0.00031 \mathrm{~ns}$ & $7060.32 \mathrm{~ns}$ & $8.3140 \mathrm{~ns}$ & $193301.66^{* *}$ \\
PB $\times$ RS $\times$ PD & $78306.10 \mathrm{~ns}$ & $0.00004 \mathrm{~ns}$ & $5061.68 \mathrm{~ns}$ & $9.8073 \mathrm{~ns}$ & $7547.88 \mathrm{~ns}$ \\
Error & 46561.92 & 0.00039 & 11971.08 & 5.1781 & 30718.45 \\
\hline
\end{tabular}

$\mathrm{ns}^{*}{ }^{*}$ and ${ }^{* *}$ : Non significant and significant at the 0.05 and 0.01 level of probability, respectively.

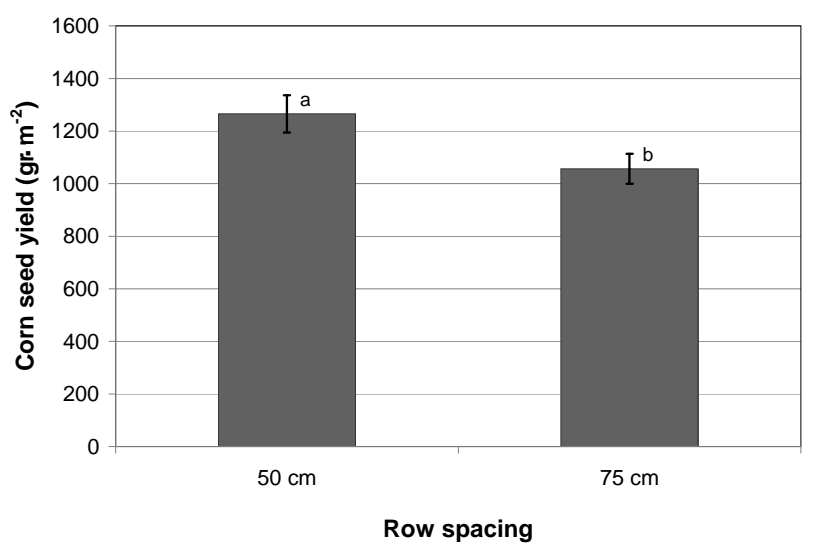

Figure 1. Corn seed yield under different row spacings. Means followed by dissimilar letters are significantly different based on LSD test at 0.05 level of probability.

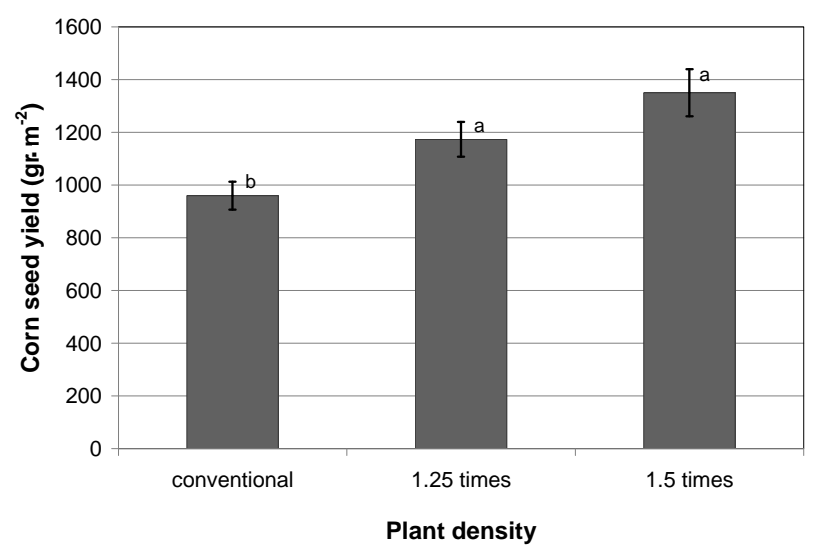

Figure 2. Corn seed yield under different plant densities. Means followed by dissimilar letters are significantly different based on LSD test at 0.05 level of probability. of corn plants per unit area that led to more efficient use of the environmental resources.

Phosphate biofertilizer did not significantly affect corn yield and yield components (Table 1). This is compatible with the findings by El-Sirafy et al. [20] who reported that biofertilizer inoculations did not influence wheat grain or straw yield. This may be explained somewhat by unfavorable condition of the soil such as high alkalinity level. Khan et al. [21] noted that phosphate biofertilizers have shown variation in their performance in related to their environmental condition. According to Gyaneshwar et al. [12] it is common to obtain phosphate solubilizing microorganisms (PSM) under laboratory conditions, while field performance by the PSM is highly variable, no increase in crop yield or P uptake was found in $70 \%$ of field experiments. Alkaline soils in the arid and semiarid environments such as many regions of Iran with high temperatures and salt concentrations may lead to poor root colonization for survival of PSM and consequently low phosphorous release by these microorganisms.

However, weed biomass significantly increased when phosphate biofertilizer was applied (Figure 3). At the conclusion of a 47-yr soil fertility study, densities of some weed species such as carpetweed (Mollugo verticillata L.) and henbit (Lamium amplexicaule L.) were greater in treatments that received annual applications of $\mathrm{P}$ fertilizer compared with the unfertilized control [22]. In another study, black nightshade (Solanum nigrum L.) populations were positively correlated with soil P level [23]. Verma et al. [24] also reported that weed growth increases with higher soil P levels. Belnap et al. [25] found that downy brome (Bromus tectorum L.) infestations were often greater on soils with higher $\mathrm{P}$ levels. 
According to Blackshaw et al. [26] shoot and root biomass of weed species enhanced with added $P$ and in most cases, this enhancement was higher for weed than crop species. It can be attributed to high ability of weeds for acquiring the soil nutrients such as $\mathrm{P}$ as reported by other researchers $[27,28]$.

Weed biomass was notably suppressed as row spacing was reduced and plant density was increased. The lowest weed biomass occurred in the $50 \mathrm{~cm}$ rows with 1.5 times the conventional plant density $\left(99,999\right.$ plants $\left.^{\circ} \mathrm{h}^{-1}\right)$ (Figure 4). This treatment diminished weed biomass by $49.37 \%$ as compared to the conventional condition (the $75 \mathrm{~cm}$ row spacing with 66,666 plants·ha ${ }^{-1}$ ) (Figure 4). However, there was no significant difference between this treatment and the treatment in which corn was planted in the $50 \mathrm{~cm}$ rows with 1.25 times the conventional plant density (Figure 4). Overall, in all plant densities, weed biomass was reduced when row spacing was decreased. But, the reduction was notably higher for the

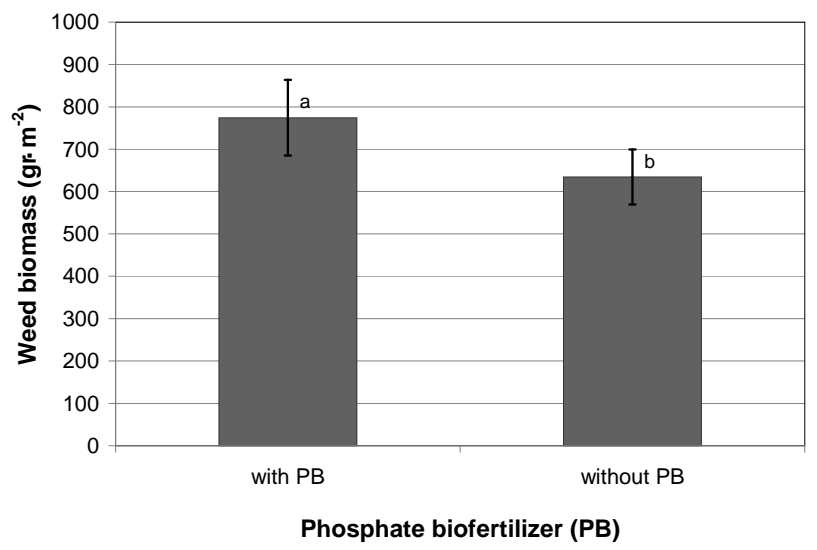

Figure 3. Weed biomass produced under different phosphate biofertilizer treatments. Means followed by dissimilar letters are significantly different based on LSD test at 0.05 level of probability.

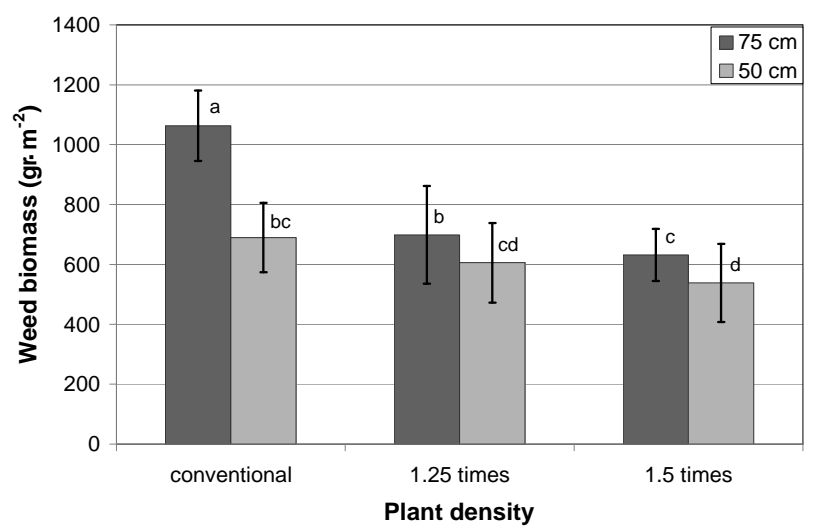

Figure 4. Weed biomass produced under different plant densities and row spacings. Means followed by dissimilar letters are significantly different based on LSD test at 0.05 level of probability. conventional plant density (Figure 4). Tollenaar et al. [29] reported that increasing corn density from 40,000 to 100,000 plants $\cdot h^{-1}$ reduced weed biomass by $56 \%$, showing that corn competitiveness with weeds can be enhanced by increasing plant density. Murphy et al. [30] suggested that narrower rows and higher corn density significantly reduced biomass of emerging weeds. Generally, corn grown in narrower rows and higher densities can be more competitive against weeds because of the fact that narrow row and high density crops close canopy earlier than wide rows and low densities. This condition affects light penetration to the soil surface, modifying weed emergence patterns and growth [31].

\section{Conclusion}

In general, this study revealed that both corn yield and weed control can be improved by alteration of the planting arrangement. So that, decreasing row spacing or increasing plant density significantly increased corn yield and reduced weed biomass. However, corn yield was not significantly affected by phosphate biofertilizer, whereas, weed biomass was notably increased when phosphate biofertilizer was applied.

\section{REFERENCES}

[1] D. N. Duvick and K. G. Cassman, "Post-Green-Revolution Trends in Yield Potential of Temperate Maize in the North-Central United States,” Crop Science, Vol. 39, No. 6, 1999, pp. 1622-1630. doi:10.2135/cropsci1999.3961622x

[2] I. Turgut, A. Duman, U. Bilgili and E. Acikgoz, "Alternate Row Spacing and Plant Density Effects on Forage and Dry Matter Yield of Maize Hybrids (Zea mays L.). Journal of Agronomy and Crop Science, Vol. 191, No. 2, 2005, pp. 146-151. doi:10.1111/j.1439-037X.2004.00146.X

[3] D. E. Farnham, "Row Spacing, Plant Density and Hybrid Effects on Corn Grain Yield and Moisture,” Agronomy Journal, Vol. 93, No. 5, 2001, pp. 1049-1053. doi:10.2134/agronj2001.9351049x

[4] G. A. Johnson, T. R. Hoverstad and R. E. Greenwald, "Integrated Weed Management Using Narrow Corn Row Spacing, Herbicides, and Cultivation,” Agronomy Journal, Vol. 90, No. 1, 1998, pp. 40-46. doi:10.2134/agronj1998.00021962009000010008x

[5] P. M. Porter, D. R. Hicks, W. E. Lueschen, J. H. Ford, D. D. Warnes and T. R. Hoverstad, "Maize Response to Row Width and Plant Density in the Northern Maize Belt," Journal of Production Agriculture, Vol. 10, No. 2, 1997, pp. 293-300.

[6] W. J. Cox, D. R. Cherney and J. J. Hanchar, "Row Spacing, Hybrid, and Plant Density Effects on Corn Silage Yield and Quality,” Journal of Production Agriculture, Vol. 11, No. 1, 1998, pp. 128-134.

[7] C. A. Shapiro and C. S. Wortmann, "Corn Response to 
Nitrogen Rate, Row Spacing and Plant Density in Eastern Nebraska," Agronomy Journal, Vol. 98, No. 3, 2006, pp. 529-535. doi:10.2134/agronj2005.0137

[8] W. D. Widdicombe and K. D. Thelen, "Row Width and Plant Density Effects on Corn Grain Production in the Northern Corn Belt,” Agronomy Journal, Vol. 94, No. 5, 2002, pp. 1020-1023. doi:10.2134/agronj2002.1020

[9] F. C. Ogbo, "Conversion of Cassava Wastes for Biofertilizer Production Using Phosphate Solubilizing Fungi,” Bioresource Technology, Vol. 101, No. 11, 2010, pp. 4120-4124. doi:10.1016/j.biortech.2009.12.057

[10] H. Besharati, F. Noorgholipour, M. J. Malakouti, K. Khavazi, M. Lotfollahi and M. S. Ardakani, "Direct Application of Phosphate Rock to Iran Calcareous Soils," International Meeting on Direct Application of Phosphate Rock and Related Appropriate Technology, Kuala Lumpur, Malaysia, 16-21 July 2001, pp. 277-279.

[11] S. A. Omar, "The Role of Rock-Phosphate-Solubilizing Fungi and Vesicular-Arbuscular Mycorrhiza (VAM) in Growth of Wheat Plants Fertilized with Rock Phosphate,” World Journal of Microbiology and Biotechnology, Vol. 14, No. 2, 1998, pp. 211-218. doi:10.1023/A:1008830129262

[12] P. Gyaneshwar, K. G. Naresh, L. J. Parekh and P. S. Poole, "Role of Soil Microorganisms in Improving P Nutrition of Plants," Plant and Soil, Vol. 245, No. 1, 2002, pp. 83-93. doi:10.1023/A:1020663916259

[13] M. Cabello, G. Irrazabal, A. M. Bucsinszky, M. Saparrat and S. Schalamuk, "Effect of an Arbuscular Mycorrhizal Fungus, Glomus Mosseae, and a Rock-Phosphatesolubilizing Fungus, Penicillium Thomii, on Mentha Piperita Growth in a Soilless Medium," Journal of Basic Microbiology, Vol. 45, No. 3, 2005, pp. 182-189. doi:10.1002/jobm.200410409

[14] H. Chung, M. Park, M. Madhaiyan, S. Seshadri, J. Song, H. Cho and T. Sa, "Isolation and Characterization of Phosphate Solubilizing Bacteria from the Rhizosphere of Crop Plants of Korea,” Soil Biology and Biochemistry, Vol. 37, No. 10, 2005, pp. 1970-1974. doi:10.1016/j.soilbio.2005.02.025

[15] A. Peix, R. Rivas, I. Santa-Regina, P. F. Mateos, E. Martinez-Molina, C. Rodriguez-Barrueco and E. Velazquez, "Pseudomonas Lutea sp. nov., a Novel Phosphate-Solubilizing Bacterium Isolated from the Rhizosphere of Grasses," International Journal of Systematic and Evolutionary Microbiology, Vol. 54, No. 3, 2004, pp. 847-850. doi:10.1099/ijs.0.02966-0

[16] S. R. Draper, “International Rules for Seed Testing," Seed Science and Technology, Vol. 13, 1985, pp. 342-343.

[17] SAS Institute, “SAS/STAT, User's Guide,” Version 9.1, SAS Institute Inc., Cary, 2003.

[18] W. E. Larson and J. J. Hanway, “Corn Production,” In: G. F. Sprague, Ed., Corn and Corn Improvement, American Society of Agronomy, Inc., Madison, 1977, pp. 625-669.

[19] R. G. Hoeft, E. D. Nafziger, R. R. Johnson and S. R. Al- drich, “Modern Corn and Soybean Production,” MCSP Publ., Savoy, 2000, 353 Pages.

[20] Z. M. El-Sirafy, H. J. Woodard and E. M. El-Norjar, "Contribution of Biofertilizers and Fertilizer Nitrogen to Nutrient Uptake and Yield of Egyptian Winter Wheat," Journal of Plant Nutrition, Vol. 29, No. 4, 2006, pp. 587599. doi:10.1080/01904160600564287

[21] M. S. Khan, A. Zaidi and P. A. Wani, "Role of Phosphate-Solubilizing Microorganisms in Sustainable Agriculture-A Review," Agronomy for Sustainable Development, Vol. 27, No. 1, 2007, pp. 29-43. doi:10.1051/agro:2006011

[22] P. A. Banks, P. W. Santelmann and B. B. Tucker, "Influence of Long-Term Soil Fertility Treatments on Weed Species in Winter Wheat,” Agronomy Journal, Vol. 68, No. 5, 1976, pp. 825-827. doi:10.2134/agronj1976.00021962006800050037x

[23] C. Andreasen, J. C. Streibig and H. Hass, "Soil Properties Affecting the Distribution of 37 Weed Species in Danish Fields,” Weed Research, Vol. 31, 1991, pp. 181-187. doi:10.1111/j.1365-3180.1991.tb01757.x

[24] R. Verma, H. R. Agarwal and V. Nepalia, "Effect of Weed Control and Phosphorus on Crop-Weed Competition in Fenugreek (Trigonella foenum-graecum)," Indian Journal of Weed Science, Vol. 31, No. 4, 1999, pp. 265266.

[25] J. Belnap, S. K. Sherrod and M. E. Miller, "Effects of Soil Amendments on Germination and Emergence of Downy Brome (Bromus Tectorum) and Hilaria Jamesii,” Weed Science, Vol. 51, No. 3, 2003, pp. 371-378. doi:10.1614/0043-1745(2003)051[0371:EOSAOG]2.0.C $\underline{\mathrm{O} ; 2}$

[26] R. E. Blackshaw, R. N. Brandt, H. H. Janzen and T. Entz, "Weed Species Response to Phosphorus Fertilization," Weed Science, Vol. 52, No. 3, 2004, pp. 406-412. doi:10.1614/WS-03-122R

[27] J. Di Tomaso, “Approaches for Improving Crop Competitiveness through the Manipulation of Fertilization Strategies,” Weed Science, Vol. 43, No. 3, 1995, pp. 491497.

[28] C. J. Swanton and S. F. Weise, "Integrated Weed Management: The Rationale and Approach,” Weed Technology, Vol. 5, No. 3, 1991, pp. 657-663.

[29] M. Tollenaar, D. E. McCoulough and L. M. Dwyer, "Phsiological basis of the genetic improvement of corn. In: G. A. Slafer, Ed., Genetic Improvement of Field Crops, Marcel Dekker Inc., New York, 1994, pp. 183-236.

[30] S. D. Murphy, Y. Yakubu, S. F. Weise and C. J. Swanton, "Effect of Planting Patterns and Inter-Row Cultivation on Competition between Corn (Zea mays) and Late Emerging Weeds,” Weed Science, Vol. 44, 1996, pp. 856-870.

[31] Z. S. Knezevic, M. J. Horak and R. L. Vanderlip, "Estimates of Physiological Determinants for Amaranthus retroflexus,” Weed Science, Vol. 47, 1999, pp. 291-296. 